\title{
CORUMBÁ DE GOIÁS: UMA HISTÓRIA DE LUTA NO CAMPO
}

\author{
Natasha Gomes Moreira Abreu ${ }^{1}$ \\ Nivaldo Santos ${ }^{2}$
}

\section{RESUMO:}

Sob a ótica dos conflitos coletivos agrários pretende-se discutir o direito de posse e proteção jurídica da propriedade da terra sob a condição de atendimento da função social. O estudo é desenvolvido a partir de revisão sobre as teorias da posse, e a sua repersonalização, e ao final, é debatida a função social nas ações de reintegrações de posse através do estudo de caso do processo de Reintegração de Posse da Fazenda Santa Mônica em Corumbá de Goiás, cuja análise crítica conta com a ajuda do método descritivo para a apresentação dos resultados e discussão sobre a decisão judicial exarada.

Palavras-chave: tutela possessória; fim social; acesso à terra; conflito agrário; ocupação.

\section{CORUMBA DE GOIAS: A HISTORY OF STRUGGLE IN THE COUNTRYSIDE}

\begin{abstract}
:
From the point of view of collective land conflicts, it is intended to discuss the right of ownership and legal protection of land ownership under the condition of attending to the social function. The study is developed based on a review of tenure theories and their repersonalization, and in the end, the social function in the reintegration of ownership actions is discussed through the case study of the Santa Monica Farm Tenure Reintegration process Corumba de Goias, whose critical analysis counts on the help of the descriptive method for the presentation of the results and discussion on the judicial decision.
\end{abstract}

Keywords: possessory protection; social order; land access; agrarian conflict; occupation.

\section{Breve considerações}

Inicialmente, é importante aduzir que a luta dos pobres do campo pelo acesso à terra é secular. A posse foi considerada como meio legítimo de ocupação da terra, depois foi desconstruída com a atribuição de seu novo caráter ilegal de invasão, tornando-se possível o acesso à terra somente àquele que detinha condições de pagar seu preço. A consolidação da imagem do posseiro de invasor foi construída historicamente pelo discurso e força dos detentores do poder, resultando no processo de marginalização.

Este ensaio, incialmente percorre pelas teorias tradicionais sobre a posse, teoria

\footnotetext{
${ }^{1}$ Mestre em Direito Agrário pela Universidade Federal de Goiás.

${ }^{2}$ Doutor em Direito pela Pontifícia Universidade Católica de São Paulo, PUC/SP. Pós-Doutor pela Pontifícia Universidade Católica de Minas Gerais, PUC Minas.
} 
subjetiva de Savigny e teoria objetiva de Ihering. O Código Civil de 2002 recepcionou a teoria de Ihering, a posse é tratada como desdobramento da propriedade, é adquirida com o exercício em nome próprio de qualquer dos poderes inerentes à propriedade, como o uso, gozo e disposição.

São abordadas as teorias sociológicas da posse de Perozzi, Saleilles e Hernandez Gil que passam a reconhecer que a posse tem uma função social a cumprir, da mesma forma que a propriedade. A teoria da posse foi repersonalizada em razão das teorias tradicionais não trazerem o elemento da função social.

Debate-se sobre o deferimento de liminares em ações de reintegração de posse vinculada ao cumprimento da função social da propriedade. Para tanto, toma-se como objeto de discussão o processo de reintegração de posse da Fazenda Santa Mônica em Corumbá de Goiás.

Justifica-se a escolha desse caso concreto, em razão deste, ter sido um conflito coletivo agrário de grandes proporções pelo número de envolvidos e de repercussão na mídia, e porque o juízo da vara de Fazendas Públicas e $2^{\mathrm{a}}$ vara cível da Comarca de Corumbá de Goiás concedeu a liminar de reintegração de posse sem audiência de justificação e qualquer menção à função social da propriedade, não levando em conta o efeito catastrófico que sua decisão provocaria.

\section{A posse e suas teorias}

Há duas teorias tradicionais sobre a posse. Uma teoria subjetiva de Savigny e outra teoria objetiva de Ihering. Para a primeira, a posse exige apenas dois elementos: um material o corpus (elemento objetivo) que é a detenção física da coisa e outro, a vontade - animus domini (elemento subjetivo) que é a intenção de possuir a coisa como dono (FRANÇA, 1991). Ressalta-se que não é a "convicção de ser dono", mas tão somente "a vontade de tê-la como sua" (PEREIRA, 2009, p.14). A subjetividade dessa teoria é demonstrada pelo animus domini. Se não houver a vontade de ter a coisa como própria, haverá simples detenção. Reconhecendo ao locatário, comodatário, depositário entre outros apenas o caráter de detentores, não gozando de proteção direta e imediata para repelir turbação ou esbulho.

Na teoria de Ihering, o elemento animus domini não existe. É objetiva a teoria porque dispensa a intenção de possuir a coisa como dono, bastando proceder como "habitualmente 
procede o proprietário" (PEREIRA, 2009, p.15). Assim, Ihering reconhece o locatário, o depositário, comodatário e etc. como possuidores.

O elemento corpus entendido como poder físico sobre a coisa, não é suficiente segundo Ihering, pois não atende todas as situações possessórias. Para ele, o corpus deve ser compreendido como a devida utilização econômica da posse. A posse foi definida como a exteriorização da propriedade (IHERING, 2005).

Para a teoria subjetiva, a posse é, ao mesmo tempo, poder de fato e de direito, pois ela se origina do fato "em sua essência" e se transforma em direito "em seus efeitos" (ALVES, 1999, p. 72) “em virtude de suas consequências, pois cria um direito pessoal que é o de invocar defesa" (SANTOS, 1999, p.27).

Diferentemente da teoria subjetiva, a teoria objetiva não admite essa dupla natureza, Ihering (2005) acredita que a posse é direito, um interesse juridicamente protegido e que se ela fosse realmente poder de fato, não haveria porquê protegê-la.

E leciona que, o possuidor para ser protegido basta demonstrar sua posse e esta proteção aproveita ao proprietário e não proprietário. A proteção possessória foi estabelecida para facilitar a prova da propriedade, e acaba sendo inevitável a proteção em relação ao possuidor não proprietário.

A posse é indissociável da propriedade, constitui a "condição de fato da utilização econômica da propriedade", "é a porta que conduz à propriedade", a proteção possessória "apresenta-se como uma posição defensiva do proprietário, a qual pode rechaçar mais facilmente os ataques dirigidos contra sua esfera jurídica" (IHERING, 2005, p.40).

\section{Conceito de posse e suas classificações}

A posse é a exteriorização da propriedade, segundo os artigos 1.204 e 1.196 ambos do Código Civil (CC/2002), a posse é adquirida com o exercício em nome próprio de qualquer dos poderes inerentes à propriedade, e o possuidor é todo aquele que tem o exercício, pleno ou não, de algum dos poderes inerentes à propriedade. É possível notar que o Código Civil de 2002 recepciona a teoria de Ihering (DINIZ, 2009; PEREIRA, 2009; GOMES, 2012; FARIA \& ROSENVALD, 2012).

Para Diniz, a posse é um desdobramento da propriedade, pois não há propriedade sem posse, "e dar proteção a esta é proteger indiretamente aquela" (2009, p. 52). 
Podem ser objeto de proteção possessória, tanto as coisas corpóreas ou incorpóreas, todas as coisas que forem objeto de propriedade podem ser objeto de posse (DINIZ, 2009; NASCIMENTO, 1986). A posse é uma "relação imediata da pessoa com a coisa, pertencente ao Direito das Coisas" (IHERING, 2005, p.57). Segundo Gomes, o "Direito das Coisas regula o poder dos homens sobre os bens e os modos de sua utilização econômica" (2012, p.1).

A posse está situada no Livro III, do Direito das Coisas. O Direito das Coisas sistematiza os direitos reais ${ }^{3}$ (ALVES, 1999; GOMES, 2012). Os direitos reais estão taxativamente expostos no artigo 1.225 do CC, como: a propriedade, superfície, servidões, usufruto, uso, habitação, direito do promitente comprador do imóvel, penhor, hipoteca, anticrese, concessão de uso especial para fins de moradia e concessão de direito real de uso (BRASIL, 2014b).

Para Gonçalves, o direito brasileiro protege a posse, que corresponde ao direito real de propriedade, como de outros direitos reais e a posse como "figura autônoma independente de um título" (2002, p.5). Essa autonomia, é resultado da compreensão da posse como um direito real (NASCIMENTO, 1986; DINIZ, 2009; GOMES, 2012; PEREIRA, 2009), ou até mesmo como um direito sui generis (GOMES, 2012).

Observa Diniz, que a posse apresenta todos os elementos do direito real, tais como: o "exercício direto, sem intermediário", "sua oponibilidade erga omnes", "sua incidência em objeto obrigatoriamente determinado" (2009, p. 52). Portanto, há que reconhecer à posse, como um direito real, pois recai sobre coisa certa, é um desdobramento da propriedade, tem eficácia erga omnes, podendo ser oposta contra todos que a desrespeitarem.

Compreendendo que a posse é "vinculação da coisa à pessoa" (GOMES, 2012, p.49) e que sua aquisição dá-se com o exercício de qualquer dos poderes inerentes à propriedade (artigo 1.204, CC), tratar-se-á a seguir da sua classificação.

A posse classifica-se como: posse justa ou injusta, posse de boa-fé ou de má-fé. A aquisição da posse pode originar de modo lícito ou não. Se adquirida de modo ilícito (violência, clandestinidade, precariedade), torna-se viciada. A presença ou ausência desses vícios objetivos (GOMES, 2012; DINIZ, 2009) influenciam na sua qualificação de posse justa ou injusta. Há ainda os vícios subjetivos (GOMES, 2012; DINIZ, 2009), que se presentes, ou

\footnotetext{
${ }^{3} \mathrm{O}$ direito real é o "poder jurídico direto e imediato do titular sobre a coisa, com exclusividade e contra todos" (GONÇALVES, 2002, p. 2). Ou, como preleciona Gomes, o direito real é o "poder imediato da pessoa sobre a coisa, que se exerce erga omnes". E essa oponibilidade erga omnes não pode ser compreendida com o uso, fruição e disposição de modos absolutos em razão da sua dimensão funcional (2012, p.11).
} 
ausentes, quando o possuidor tem ou não a convicção de que sua posse é legítima, influenciam na qualificação da posse, considerada de boa-fé ou de má-fé.

A posse será justa quando não for violenta, clandestina ou precária, conforme artigo 1.200, CC. Logo, a posse injusta (ilícita) é aquela adquirida por meios violentos, clandestinos e precários que afrontam o Direito (BRASIL, 2014b).

Posse violenta é a utilização da força física ou violência moral, clandestina entendese como oculta, feita às escondidas, de que tem interesse de recuperar a coisa possuída e precária com abuso de confiança, a partir da recusa em restituir a coisa (GOMES, 2012; DINIZ, 2009; PEREIRA, 2009).

A posse justa deve ser pública e contínua:

pública, para que o interessado na sua extinção possa opor-se a que continue a ser exercida por aquele que se apresenta como legítimo possuidor. Deve ser, do mesmo modo, contínua, porquanto o seu exercício manso e pacífico confirma, constantemente, a legitimidade de sua aquisição (GOMES, 2012, p.49).

A posse de boa-fé está prevista nos artigos 1.201 e 1.202, CC. Será de boa-fé quando o possuidor ignora o vício, ou obstáculo que impede a aquisição da coisa. Ignora que possui indevidamente a coisa (BRASIL, 2014b). Segundo Pereira (2009), falta consciência ao possuidor de que ele está causando um dano a outro. Ou, como Gomes (2012) discute, é preciso que, o possuidor esteja convencido de que não prejudica outrem, por erro de direito invencível. A má-fé portanto, está na consciência de que há obstáculo ou vício que o impede de adquirir a coisa de forma legítima.

\section{Perda e Proteção da Posse}

O Código Civil brasileiro previu situações de perda da posse nos arts. 1.223 e 1.224. Cessa a posse contra a vontade do possuidor, quando este perde o poder sobre a coisa. Considera perdida a posse pelo esbulho não presenciado, ou sabendo-o nada faz para retomar a coisa, ou no intuito de recuperá-la, é repelido violentamente (BRASIL, 2014b).

Perde-se a posse, dentre as diversas situações que venham a "cessar o poder sobre a coisa ou a faculdade de exercer algum dos direitos inerentes à propriedade", usar, dispor, gozar (PEREIRA, 2009, p. 42). A perda da posse pode ocorrer, por não se empenhar no sentido de reavê-la, ou, por outra pessoa tê-la adquirida; dessa forma, destacam-se dois modos 
de perda da posse, dentre outros: pela posse de outrem, decorrente de esbulho de terceiro, neste caso o possuidor perde a coisa contra sua vontade, e por abandono, em que o possuidor não manifesta interesse em servir da coisa, não é diligente (FARIA \& ROSENVALD, 2012).

A proteção possessória pode ser invocada para resguardar a posse diante de turbação, esbulho, ou ameaça. Um dos efeitos da posse é o "direito a interditos" (GOMES, 2009, p. 93). Os interditos possessórios ou ações possessórias são instrumentos processuais que servem de defesa da posse, contra a ameaça, turbação ou esbulho da posse e são as ações de reintegração e manutenção da posse e interdito proibitório.

As ações possessórias têm procedimento especial, no intuito de promover rápida solução do conflito, e estão previstas no artigo 560 e seguintes do Código de Processo Civil. O prazo para propor ações de manutenção e reintegração de posse é decadencial, de ano e dia contado da agressão, passado esse prazo, o procedimento será ordinário. Os autores Faria \& Rosenvald (2012) denominam a ação com rito especial de "ação de força nova", pois requerida dentro do prazo legal, e "ação de força velha", para aquela proposta fora do prazo previsto. Esclarecem que, o prazo decadencial não importa em perda para o direito ao interdito possessório. O prejuízo ocorre tão somente, no que se refere, à celeridade processual e à liminar. Para a ação de interdito proibitório não se aplica o prazo decadencial, pois ela deve ser proposta em caso de justo receio de ameaça à sua posse.

A ação de manutenção da posse é medida cabível de defesa para quando o possuidor sofre turbação no seu direito. Turbação é "todo ato que embaraça o livre exercício da posse, haja, ou não, dano, tenha o turbador, ou não, melhor direito sobre a coisa. Há de ser real, isto é concreta, efetiva, consistente em fatos" (GOMES, 2012, p.95).

Na reintegração de posse, o esbulho acontece quando o possuidor é despossado da coisa por violência, clandestinidade ou precariedade. Também chamada de "ação de força nova espoliativa, pressupõe ato praticado por terceiro que importe, para o possuidor, perda da posse, contra a sua vontade" (GOMES, 2012, p.97).

No interdito proibitório, o possuidor diante do receio de ameaça de turbação ou esbulho previne-se com a obtenção de mandado judicial para resguardar-se de violência eminente.

\section{A função social da posse}


As teorias clássicas da posse não esgotam a abordagem sobre a posse. Em razão das novas exigências sociais, há que se reconhecer que a posse tem uma função social a cumprir.

A teoria da posse foi repersonalizada (SANHUDO, 2011; DINIZ, 2009; GOMES, 2012; TARTUCE, 2014), a partir das contribuições de Silvio Perozzi, Raymond Saleilles e Hernandez Gil. Estes autores fortaleceram a posse, ao determinar a sua autonomia em face da propriedade, ao aprofundar o caráter econômico da posse e defender sua função social.

Na V Jornada de Direito Civil de 2011, elaborou-se o enunciado $n^{\circ} 492$ sobre a função social da posse, como sendo, a que "constitui direito autônomo em relação à propriedade e deve expressar o aproveitamento dos bens para o alcance de interesses existenciais, econômicos e sociais merecedores de tutela" (TARTUCE, 2014, p.864).

O Código Civil de 2002 recepcionou a teoria de Ihering, mas os autores Zavascki (2004) e Tartuce (2014) acreditam que o Código Civil brasileiro tem traços também da tese da posse-social de Silvio Perozzi, Raymond Saleilles e Hernandez Gil, ou seja, da mesma forma que, a propriedade tem uma função social a cumprir, reconhecida pela Lei Maior, "o mesmo deve ser dito em relação à posse" (TARTUCE, 2014, p.865). Para Tartuce (2014), o debate entre as teorias Savigny e Ihering está superado.

É percebível que, no debate entre as teorias clássicas tradicionais da posse entre Savigny e Ihering discutidas anteriormente, não há discussão sobre o aspecto social da posse, portanto, como Tartuce (2013) expõe, as teorias estão obsoletas a partir das novas teorias que funcionalizaram a posse. Para Zavascki (2004) a função social diz respeito, mais ao fenômeno da posse, que propriamente, ao direito de propriedade. Segundo ele, a posse permeia de forma implícita a Constituição Federal e sua função social orienta o Código Civil.

O intuito não é traçar um novo conceito sobre a posse a partir das teorias sociológicas de Silvio Perozzi, Raymond Saleilles e Hernandez Gil, mas demonstrar que, a partir delas, abriu-se o caminho para a discussão da função social da posse, porque as teorias clássicas não atendem à realidade social de milhares de trabalhares rurais desvalidos, sem acesso à terra, enquanto o país tem um quadro caótico, antissocial, de concentração de propriedades de terras ociosas pela especulação imobiliária e propriedades descumpridoras da função social.

Tem-se em vista, por conseguinte, as novas exigências sociais conduzidas pela Carta Política de 1988, tais como o primado da dignidade da pessoa humana, os valores sociais do trabalho e da livre iniciativa como fundamentos do Estado Democrático de Direito, rumo à 
construção de uma sociedade justa, fraterna, com a promoção do bem de todos, do desenvolvimento nacional e com o fim de erradicar a pobreza, a marginalização e reduzir as desigualdades sociais.

Para as teorias sociológicas, a posse não é uma mera exteriorização da propriedade.

É fundamental uma reinterpretação forjada em valores sociais que a reconheçam como poder fático de ingerência socioeconômica em relação a determinada coisa, cumprindo a função social. Desse modo, a posse é um fenômeno capaz de se sobrepor à própria propriedade em face de sua densidade e autonomia" (SANHUDO, 2013, p.87).

Na teoria de Raymond Saleilles, a posse é uma "relação de apropriação econômica e não jurídica", ou seja, uma apropriação econômica, que permite a exploração da coisa (BOLONHINI JUNIOR, 2013, p.218). Raymond Saleilles destaca a autonomia da posse diante da propriedade, "há uma relação de fato suficiente para estabelecer a independência econômica do possuidor" (SANHUDO, 2013, p.72).

Silvio Perozzi atribui à posse o caráter social, um cunho sociológico. A posse é "um dever de abstenção da sociedade em relação a uma coisa objeto do poder de uma pessoa que, certo desse dever de abstenção mencionado, apreende a coisa como possuidor" (BOLONHINI JUNIOR, 2013, p.219).

A posse ganha estabilidade social e jurídica, pelo dever de abstenção da sociedade, mas não caracteriza uma relação jurídica, não depende da regulação estatal, porque "tem como base estrutural uma relação ético-social calcada num costume que integra a moralidade da sociedade; portanto, a posse é parte integrante da consciência social, não dependendo da vontade do Estado" (BOLONHINI JUNIOR, p.220).

A posse para Silvio Perozzi é fato social, correlação entre poder de apreensão de coisa por uma pessoa, independentemente da intenção de ser dono, ou da aparência de dono e um dever de abstenção da sociedade.

Trata-se de uma propriedade-função. "A posse se parece com a propriedade, enquanto não é ela mesma uma propriedade; precisamente ela é uma propriedade social, um estado de liberdade de ação com relação à coisa vigente por forças naturais" (PEROZZI, 1906, p.828 apud BOLONHINI JUNIOR, 2013, p.221).

Hernandez Gil observa a posse como sendo, uma relação assentada no aspecto social e com reflexos jurídicos, um fenômeno social primário inerente à condição humana porque 
se exterioriza por meio da ação humana, especialmente o contato do homem com as coisas que se encontram ao seu alcance, que estão ao seu redor, a partir de uma relação econômico-política, independentemente da espécie de estrutura econômicosocial que se tem em vista, isto é, a posse como fenômeno social é observada tanto nas economias de mercado, quanto nas economias mais fechadas (BOLONHINI JUNIOR, 2013, p.61).

Hernandez Gil aponta que, a propriedade difere da posse, pois naquela, há uma relação de exclusão, e nesta, uma relação social primária. A posse pode ser vista, como uma necessidade humana e como instrumento de trabalho. A função social da posse promove a existência digna do homem pela distribuição equitativa de renda, "atendendo-se assim, o piso mínimo vital da existência humana, não só no que se refere à moradia e subsistência, mas também em relação ao trabalho desenvolvido pelo indivíduo e coletividade" (BOLONHINI JUNIOR, 2013, p.96). A posse merece o tratamento jurídico que se dá à propriedade, no que tange à função social.

A propriedade, quanto a posse, podem existir separadamente, mas para Torres (2007, p.303), a propriedade sem posse é "um recipiente oco, vazio, tendo em tal situação, função econômica e social limitadas”. A propriedade, conceito abstrato (MARÉS, 2003) subsiste sem exercício da posse porque está amparada no título aquisitivo, por outro lado, a posse não sobrevive sem seu exercício. Desta forma, assinala que, a função social torna-se mais evidente na posse, que na propriedade.

O autor, parte da ideia de que, para cumprir a função social da propriedade é necessário o "exercício da faculdade de uso do bem, este só se materializa pela posse", então, na verdade, a função social é da posse, cujo proprietário ao exercê-la, atende aos compromissos sociais (TORRES, 2007, p.303).

Zavascki (2004) nesse sentido, assevera que, a função social diz respeito mais ao fenômeno da posse, que propriamente ao direito de propriedade.

A obrigação do proprietário em manter a propriedade da terra cumprindo a função social dá-se com o exercício efetivo da posse. A ausência da função social da propriedade implica em ausência da função social da posse; e a ausência da função social nos dois institutos implica em ausência de proteção pelo Direito.

A função social, elevada constitucionalmente, deve estar presente nos dois institutos: propriedade e posse, tanto o proprietário, quanto o possuidor, deverão segundo Castro, "pautar a sua conduta de moldo a atender, além da destinação econômica do bem, mas também a sua função ou destinação social que deles se espera” (2011, p.123). Se a 
Constituição reconhece a função social da propriedade, o mesmo deve ser dito em relação à posse (TARTUCE, 2014).

Para Dantas (2013) e Araújo Neto (2012), o princípio da função social deve ser avaliado na tutela da posse e propriedade da terra, sendo que, no caso de desfuncionalização desta última, a primeira deve prevalecer ao ocupante pelo seu exercício da posse funcionalizada ${ }^{4}$.

Por todo o exposto, defende-se a ideia de que a função social da propriedade é desempenhada com o cumprimento da função social da posse que conforme preceituado por Marés, a propriedade que não cumpre a função social da terra é uma "espécie de coisa de ninguém, desapropriável, mas também ocupável, por quem puder fazê-la útil à sociedade" (2003, p.125):

\begin{abstract}
Por outro lado, aquele que faz a terra destinada ao uso privado cumprir sua função social tem direito a ela e a seus frutos, ainda que proprietário não seja, sem que o eventual titular do direito possa invocá-lo contra o uso dado. Ao contrário de cometer ato ilícito, aquele que ocupa uma terra que não está cumprindo sua função social, para fazê-la cumprir, age de acordo com a lei e o interesse social, merece prêmio, não sanção. (MARÉS, 2003, p.134).
\end{abstract}

Portanto, a ocupação torna-se legítima diante dessa situação. Neste caso, a função social da posse pelo ocupante merece proteção jurídica, em detrimento do titular de domínio, que não observa a função social da propriedade da terra.

A seguir será discutida a exigência da função social no conflito agrário instalado, no confronto entre ocupante e proprietário em torno da efetiva utilização do bem, em sede de liminar de reintegração de posse.

\title{
As ações possessórias e a função social
}

O CPC estabeleceu que, em caso de esbulho, o possuidor tem o direito de ser reintegrado na sua posse e para tanto, deverá provar os seguintes elementos: a sua posse, o esbulho praticado pelo réu, a data do esbulho, a perda da posse. E para obter a antecipação de tutela em liminar de reintegração de posse, bastará que a petição esteja instruída com esses

\footnotetext{
${ }^{4} \mathrm{~A}$ posse funcionalizada pode ser também denominada de posse qualificada pelo trabalho e moradia.
} 
elementos para o seu deferimento, no caso contrário, o juiz marcará audiência de justificação e só depois decidirá sobre o pedido de liminar.

O Novo Código de Processo Civil não atendeu as demandas dos conflitos fundiários rurais. Na nova redação do art. 561 não houve a inclusão da função social da propriedade como um dos requisitos para o deferimento da ação de reintegração de posse.

Ficou de lado, novamente, o tratamento da função social da propriedade nas ações possessórias, restando incoerente com os objetivos de construção de um sistema processual civil voltado para a resolução dos conflitos, abertura para as necessidades e demandas sociais e em sintonia com a própria Lei Maior.

Uma questão que foi discutida sobre a posse, é a figura do possuidor-proprietário que se confundem em uma pessoa, porque nesta situação, a posse é um desdobramento do direito de propriedade. Neste caso, em razão da consagração da função social da propriedade na Constituição deve repercutir segundo Didier Júnior (2008), no regramento infraconstitucional de tutela processual da posse.

Leonetti (2009) defende que, o magistrado, no caso concreto de ações possessórias, é obrigado a examinar o cumprimento da função social da propriedade e deverá julgar improcedente se não houver a observação da função social.

Segundo Marés (2003; 2006), o proprietário que não cumpre a função social não está protegido pelo Direito, não tem direito de socorrer-se, não podendo utilizar-se dos meios jurídicos de proteção, como as ações possessórias. Deverá provar o cumprimento da função social nos três requisitos econômico, social e ambiental como reza o artigo $186^{5}$ da CF.

Para Zavascki (2005), quem não cumpre a função social da propriedade perde as garantias de proteção da posse inerentes à propriedade e as ações possessórias. Desta forma, nas ações possessórias a prova da função social da propriedade é uma exigência, pois a aplicação das normas civilistas e processuais civis devem ser feitas à luz da CF.

Para Abib (2005) a interpretação não pode ser outra, a função social da propriedade é requisito para deferimento nas ações possessórias, sem ela não há proteção pela lei. Se "o proprietário que não exerce a sua posse de forma adequada, e não confere à propriedade uma

\footnotetext{
${ }^{5}$ Art. 186. A função social é cumprida quando a propriedade rural atende, simultaneamente, segundo critérios e graus de exigência estabelecidos em lei, aos seguintes requisitos:

I - aproveitamento racional e adequado;

II - utilização adequada dos recursos naturais disponíveis e preservação do meio ambiente;

III - observância das disposições que regulam as relações de trabalho;

IV - exploração que favoreça o bem-estar dos proprietários e dos trabalhadores. (BRASIL, 2014c).
} 
função social na forma da Constituição, não deverá pois, obter a proteção jurisdicional” (p.8990).

Castro (2011) entende perfeitamente possível discutir diante de conflitos possessórios que o proprietário demonstre o cumprimento da função social da propriedade.

Ferreira et al (2013) consideram que é cabível, a partir do regramento constitucional, a exigência quanto ao cumprimento da função social da propriedade como requisito para deferimento da liminar ou procedência da ação possessória.

Marques (2010) expõe que, o proprietário tem o direito de ser reintegrado em sua posse, desde que atendidos os requisitos previstos no artigo 561 do CPC e comprove o cumprimento da função social na integralidade do artigo 186 da CF.

De acordo com Bercovici (2001), a partir da CF de 1988, tornou-se inviável a proteção possessória de quem não cumpre a sua função social.

Dentre outros autores que defende a aplicação do CPC à luz da CF, e portanto, cabível a exigência do cumprimento da função social da propriedade para deferimento das ações possessórias, estão: Barroso \& Rezek (2007), Bertan (2009), Carapumala (2001), Castro (2012), Comparato (1997), Chemeris (2003), Dantas (2013), Dresch (2006), Guterres \& Crocetti (2005), Jesus (2005), Lemos (2012), Moreira (2004), Orrutea (1998), Peres Neto (2010), Sanhudo (2011), Tepedino \& Schreider (2002) e Torres (2007).

Como lembra Didier Júnior (2008), não é possível abordar os procedimentos de tutela da posse ignorando a existência da norma constitucional, que estrutura todo o sistema infraconstitucional.

Sabendo que, o possuidor-proprietário para cumprir a função social da sua propriedade da terra, é preciso exercer a posse, sendo na verdade, a função social mais presente na posse.

Por isso, é plenamente possível a exigência da comprovação da função social da propriedade para proteção possessória, porque como lembra Didier Júnior "se a tutela processual serve à tutela do titular do domínio, se esse domínio não é digno de proteção jurídica, porquanto em desacordo com o modelo constitucional do direito de propriedade" (2008, p.4), não haverá proteção do instrumento de realização desse direito, que é a posse, ou seja, restando o indeferimento da tutela processual da posse.

Para o autor, na proteção processual possessória é necessária a prova do cumprimento da função social. Assim, na aplicação do artigo 561 do CPC, deverá o 
intérprete, analisar: a sua posse, o esbulho praticado pelo réu, a data do esbulho, a perda da posse e o pressuposto implícito a função social, decorrente do modelo constitucional de propriedade.

\section{A ocupação em Corumbá de Goiás}

Trata-se de conflito agrário coletivo que envolve 3.500 (três mil e quinhentas) famílias integrantes do MST (ao todo são aproximadamente 10 mil pessoas), que ocuparam a fazenda Santa Mônica situada nos municípios de Corumbá de Goiás, Abadiânia e Alexânia. A concentração das famílias na fazenda está na localização do município de Corumbá de Goiás. A fazenda tem aproximadamente 30 mil hectares.

A ocupação da fazenda Santa Mônica ganhou repercussão na impressa local e nacional. As principais forças sociais estão presentes na discussão de uma resolução pacífica do conflito instalado, e são elas: coordenador estadual do MST em Goiás, líderes do MST, as milhares de famílias acampadas, Secretaria de Direitos Humanos da Presidência da República, Superintendência Regional do INCRA, Secretaria de Segurança Pública do Estado de Goiás, Polícia Militar, Presidente da Comissão de Reforma Agrária da Assembleia Legislativa do Estado de Goiás, Procurador da República, Presidente da Comissão de Direitos Humanos da Assembleia Legislativa do Estado de Goiás, advogado da parte autora, Ouvidoria Agrária Nacional, Comissão Nacional de Combate à Violência no Campo, Comissão Pastoral da Terra, Comissão de Conflitos Fundiários da Secretaria de Segurança Pública em Goiás, Tribunal de Justiça, MP, Ouvidoria Geral da SSP/GO, Superintendência dos Direitos Humanos do Estado de Goiás e Comissão de Direitos Humanos da OAB/GO.

\section{A decisão liminar de reintegração de posse da fazenda Santa Mônica}

A medida de tutela antecipatória em liminar na ação de reintegração de posse de força nova é concedida em dois momentos. O primeiro: quando a petição estiver instruída com a presença dos requisitos do artigo 561 do CPC (a posse, o esbulho praticado pelo réu, a data do esbulho e a perda da posse). Além disso, exige-se o requisito implícito decorrente do arcabouço constitucional que é a prova da função social da propriedade como estudado anteriormente. 
Portanto, o juiz no julgamento liminar da ação possessória deve exigir a prova ainda que mínima, do cumprimento da função social da propriedade, tal como delineado no artigo 186 da CF. Na aplicação do artigo 561 do CPC, deverá o intérprete, analisar: a posse, o esbulho praticado pelo réu, a data do esbulho, a perda da posse e o cumprimento da função social da propriedade.

E no segundo momento, quando não devidamente instruída a petição, deverá o juiz designar audiência de justificação para comprovação do alegado, para então, manifestar sobre o deferimento da tutela antecipatória em liminar (BRASIL, 2014a).

Analisando o caso concreto, no primeiro momento, a liminar foi concedida determinando a proibição do MST em turbar ou esbulhar as terras da fazenda Santa Mônica, arbitrando multa em caso de descumprimento da proibição judicial no valor de $\mathrm{R} \$ 50.000,00$ (cinquenta mil) reais, além da cominação de multa diária no valor de $\mathrm{R} \$$ 100.000,00 (cem mil reais) para cada dia de permanência no imóvel em caso de ocupação. Na fundamentação da decisão não houve menção da função social da propriedade, o juiz limitou-se na demonstração do direito de posse e no fundado receio e eminente de dano, ameaça à posse.

Como durante o processo, as famílias acabaram ocupando a Fazenda Santa Mônica, a parte autora reforçou o pedido de conversão de interdito proibitório em reintegração de posse; e a concessão da liminar de reintegração de posse inaudita altera pars. O magistrado deferiu o pedido e concedeu a liminar de reintegração de posse fundamentando sua decisão de que se encontram presentes os pressupostos autorizadores para a reintegração de posse, uma vez que, comprovado a posse e a propriedade do requerente e o esbulho sofrido através da invasão da propriedade rural, manifestou que mesmos cientes do interdito proibitório, os integrantes e líderes do MST resolveram invadir a fazenda em descumprimento da ordem judicial.

Concedeu o prazo de 48 (quarenta e oito) horas para desocupação pacífica do imóvel rural, autorizado o desforço policial em caso de resistência à ordem judicial. Ressalta-se que, na decisão, não há qualquer menção sobre a função social da propriedade.

Ainda que se trate de uma decisão de antecipação de tutela, ela tem o efeito de ser satisfativa, mesmo possível, não é razoável, diante dos conflitos agrários coletivos, que os magistrados decidam sem ouvir o outro lado, sem pensar que sua decisão nega também o direito de 10 mil pessoas ocupantes.

É importante destacar que o ato de "invadir" é tomar com força "alguma coisa de alguém”, já ocupar é "preencher um vazio - no caso, terras que não cumprem sua função 
social" (SILVA, J. G., 1996, p. 116). Quando o MST ocupa significa que ele não reconhece o direito de propriedade, sendo ilegítimo o direito do proprietário em razão do descumprimento da função social (ANDRADE, 2008).

Tárrega et al (2013, p. 16) entendem que o ato de ocupar é uma estratégia de ação, que a "ação dos movimentos sociais de ocupar terras, passou a exercer o papel de pressão sobre o estado, para a garantia de um estoque mínimo de terras para a reforma agrária". É uma forma de cobrar do Estado o cumprimento da política de reforma agrária e de denunciar propriedades descumpridoras da função social, que deste modo, encontram-se em situação de ilegalidade.

Dessa forma, reconhece-se que a ação de ocupação é legítima, pois a sua legitimidade está na luta pela Reforma Agrária, justa distribuição da terra, nos objetivos fundamentais da República Brasileira de construir uma sociedade livre, justa e solidária, garantir o desenvolvimento nacional, erradicar a pobreza, a marginalização e reduzir as desigualdades sociais e regionais.

Como discorrido, a forma dos movimentos sociais de pressionar o governo para programar a reforma agrária e ganhar a atenção da sociedade, é a adoção de estratégia de ocupação. De acordo com Graf (2005) a reforma agrária é uma necessidade econômica e social, visto que as propriedades ociosas agricultáveis poderiam ser distribuídas àqueles que têm "vocação agrícola" (p. 93), garantindo o acesso à terra.

A reforma agrária tem como causa básica a pobreza rural, que acarreta a pobreza urbana e seu objetivo é a "eliminação da miséria e dos efeitos negativos que ela provoca na estrutura econômica, social e política do país" (SAMPAIO, 1988, p. 09).

Segundo Borges (1987, p. 139), "a terra existe para ser utilizada, para dela se tirar o sustento do homem. Não se admite mais que seja mantida improdutiva a terra fértil. Tal seria um crime de lesa-humanidade". A terra que não desempenha sua função social, não pode e não merece proteção possessória. É “incongruente com a norma constitucional e a menos legis deferir a proteção possessória ao titular de domínio, que não cumpre integralmente sua função social” (FACHINI, 2000, p. 285).

Assim, esse desenvolvimento do MST de ocupação "está interligado à sua capacidade de se engajar em uma forma particular de conflito social", é considerado ativismo público. A sua luta é "organizada, politizada, visível, autônoma, periódica e não violenta de 
conflito social". As ações ativistas buscam atrair a atenção pública, influenciar as políticas estatais e modificar os valores da sociedade (CARTER, 2010, p. 203).

Portanto, considerar a ação dos movimentos sociais como esbulhatória corrobora com "o processo de criminalização do ativismo público ou das posturas sociais de cobrança de direitos pelo estado" (TÁRREGA et al, 2013, p. 17).

O CPC deve passar por uma contaminação constitucional (STRECK, 2014, p. 348), visto que, a Constituição é "topos hermenêutico" (STRECK, 2014, p.345) que conforma a interpretação do restante do sistema jurídico, tem "posição hierárquico-normativa superior, em relação às demais normas do ordenamento jurídico. (CANOTILHO, 2003, p. 1.147). Não condicionar o CPC a uma "filtragem hermenêutico-constitucional" (STRECK, 2014, p.382) é tornar a Constituição ineficaz, como preceituado por Chacon (2013), a Lei Maior deve ser considerada explícita ou implicitamente em toda a prática que realizar o exegeta, de modo que, seus dispositivos tenham força normativa.

O Poder Judiciário, quando decide a partir da norma procedimental (Código de Processo Civil) e sua norma material (Código Civil), ignorando o preceituado pela Constituição Federal colabora para a eternização dos conflitos no campo. Uma postura distante das mazelas sociais e que sepulta a própria Carta Política ao não dar efetividade e submetê-la ao garrote da norma processual.

\section{Considerações finais}

Examinando a decisão liminar, ficou clara a apatia - que denota uma posição política - do Poder Judiciário em não discutir a função social da propriedade ou da posse como requisito essencial para a concessão de liminar de reintegração de posse, que como visto anteriormente, a função social está presente nos dois institutos.

A decisão do juízo de primeiro grau fundou-se no trato de conflitos individuais, sem reconhecer que está evidenciada a natureza de conflito agrário de caráter coletivo, cujo envolvimento de mais de 3.500 famílias, chega a um total de quase 10 mil pessoas, segundo informações nos autos. Não houve o tratamento da questão sob a ótica do direito agrário, que tem como princípio básico da sua construção dogmática a função social que é norma cogente da Constituição Federal. 
Sabe-se que a liminar é uma decisão judicial de antecipação de tutela no início da lide, uma medida de urgência, provisória e satisfativa. Em razão de ser satisfativa, pode provocar conflito social quando prolatada sem a presença das forças sociais, sem considerar o direito dos demais, porque de antemão bloqueia a capacidade de pensar nos demais personagens sociais envolvidos. No presente caso, o juiz sequer designou audiência de justificação, deferiu a liminar sem considerar a proporção do conflito instalado e os prováveis efeitos sociais graves e irreparáveis de sua decisão.

De um modo geral, o discurso jurídico (notoriamente vai configurando-se como uma prática) do Poder Judiciário continua marcado pela visão conservadora do direito, sem desvencilhar da concepção individualista do direito de propriedade. As expressões: "invasão", “esbulho", “esbulhadores", “invasores” apareceram nas decisões de primeiro e segundo grau.

Interpretar a função social da propriedade, entendida como o exercício da posse e um dos requisitos para o deferimento da liminar de reintegração de posse, é um modo perfeitamente possível pela $\mathrm{CF} / 88$ que atende as reinvindicações sociais do acesso à terra, que responde às demandas dos conflitos pela posse e propriedade da terra.

\section{Referências}

ABIB, Paulo Abiguenem. A função social da propriedade imóvel sob a égide da Constituição Federal e sua efetividade no processo. 2005. 112 f. Dissertação (Mestrado em Direito). Faculdade de Direito de Vitória, 2005.

ALVES, José Carlos Moreira. Posse. $2^{\text {a }}$ ed. $1^{\text {o }}$ tomo. Rio de Janeiro: Forense, 1999.

ANDRADE, Tânia. Experiência concreta de mediação de conflitos agrários: Pontal do Paranapanema. In: ARAÚJO NETO, Henrique Batista de. A envergadura constitucional da posse qualificada na desapropriação privada. 2012, 108 f. Dissertação (Mestrado em Direito). Universidade Federal do Rio Grande do Norte, 2012.

ARAÚJO, Telga de. A propriedade e sua função social. Direito agrário brasileiro. In: LARANJEIRA, Raymundo (coordenador). Direito agrário brasileiro. São Paulo: LTr, 1999.

BARROSO, Lucas Abreu; REZEK, Gustavo Elias Kallás. O código civil e o direito agrário. Rivista di Diritto Agrario, v. 2, p. 259-293, 2007.

BERCOVICI, Gilberto. A Constituição de 1988 e a função social da propriedade. Revista de direito privado, n. 7, p. 83, 2001.

BERTAN, José Neure. Propriedade privada e função social. $1^{\text {a }}$ ed., $3^{\text {a }}$ reimp. Curitiba: Juruá, 2009. 
BOLONHINI JUNIOR, Roberto. Uma nova visão fático-social da posse, 2013, 276f. Tese (Doutorado em Direito Civil Comparado). Pontifícia Universidade Católica de São Paulo, 2013.

BORGES, Paulo Torminn. Institutos básicos do direito agrário. $5^{\text {a }}$ ed. São Paulo: Saraiva, 1987.

BRASIL. Código Civil. Disponível em:

<http://www.planalto.gov.br/ccivil_03/leis/2002/L10406compilada.htm>. Acesso em: 09 de set. 2014b.

BRASIL. Constituição da República Federativa do Brasil de 1988. Disponível em: <http://www.planalto.gov.br/ccivil_03/constituicao/constituicao.htm>. Acesso em: 17 de jul. $2014 c$.

BRASIL, Código de Processo Civil de 2015. Disponível em:

<http://www.planalto.gov.br/ccivil_03/_Ato2015-2018/2015/Lei/L13105.htm\#art1046>.

Acesso em: 07 de jun. 2015.

BUAINAIN, Antônio Márcio. Reforma agrária por conflitos: A Gestão dos Conflitos de Terras no Brasil. In: BUAINAIN, Antônio Márcio (coord). Luta pela terra, reforma agrária e gestão de conflitos no Brasil. Campinas: UNICAMP, 2008.

CANOTILHO, J.J. Gomes. Direito constitucional e teoria da constituição. $7^{\mathrm{a}}$ ed. $4^{\mathrm{a}}$ reimp. Coimbra: Almedina, 2003.

CARAPUMALA, Emmannuel. A proteção possessória em face da determinação constitucional de função social da propriedade. Revista da Faculdade de Direito do Alto Paranaíba, v. 5, n. 5, p. 40-52, 2001.

CARTER, Miguel. Origem e consolidação do MST no Rio Grande do Sul. In: Combatendo a desigualdade social: o MST e a reforma agrária no Brasil. São Paulo: UNESP, 2010.

CASTRO, Áurea Lúcia Chaves. A transformação do direito de propriedade e da posse no século XXI: a importância do princípio constitucional da função social e o desenvolvimento da posse "maxiqualificada". 2011, 153f. Dissertação (Mestrado em Direito). Pontifícia Universidade Católica de Minas Gerais, 2011.

CASTRO, Joana Darque Couto de; JÚLIO, Ana Célia de; CABRAL, Francisco Leite. Da reintegração de posse na propriedade rural. Judicare, v. 2, n. 2, 2012.

CHACON, Eduarda. Da hermenêutica jurídica na obra de Tercio Sampaio Ferraz Junior à interpretação conforme a Constituição. Revista dos Tribunais, Revista de Direito Constitucional e Internacional, v. 83, p. 119, 2013.

CHEMERIS, Ivan Ramon. A função social da propriedade: o papel do Judiciário diante das invasões de terras. São Leopoldo: Unisinos, 2003.

COMPARATO, Fábio Konder. Direitos e deveres fundamentais em matéria de propriedade. Revista CEJ, v. 1, n. 3, p. 92-99, 1997.

DANTAS, Marcus Eduardo de Carvalho. Função social na tutela possessória em conflitos fundiários. Revista Direito GV, v. 9, n. 2, p. 465-488, 2013.

DIDIER JÚNIOR, Fredie. A função social da propriedade e a tutela processual da posse.

Revista dos Tribunais, Revista de Processo, v. 161, p. 9, 2008. 
DINIZ, Maria Helena. Curso de direito civil brasileiro. Direito das Coisas. $24^{a}$ ed. v. 4. São Paulo: Saraiva, 2009.

DRESCH, Renato Luís. Aspectos jurídicos das liminares possessórias em Ações coletivas sobre a posse de terras rurais. Revista de Direito Agrário: Instituto Nacional de Colonização e Reforma Agrária, ano 19, n. 18, p. 141-161, 2006.

FACHINI, Luis Edson. A Justiça dos Conflitos no Brasil. In: STROZAKE. Juvelino José. A Questão Agrária e a Justiça. São Paulo: RT, 2000.

FARIA, Cristiano Chaves; ROSENVALD, Nelson. Curso de Direito Civil. Direitos Reais. 8 ed., v. 5. Salvador: Podivm, 2012.

FERREIRA, José Adegmar; TÁRREGA, Maria Cristina Vidotte Blanco; FRANCO, Rangel Donizete. A função social da terra e as ações possessórias. Revista da Faculdade de Direito da UFG, v. 37, n. 2, p. 142-163, 2013.

FRANÇA, R. Limongi. Instituições de direito civil. 2a ed. São Paulo: Saraiva, 1991.

GOMES, Orlando. Atual. Luiz Edson Fachin. Direitos reais. $21^{\mathrm{a}}$ ed., rev., atual. Rio de Janeiro: Forense, 2012.

GONÇALVES, Carlos Roberto. Direito civil: direito das coisas. $5^{\text {a }}$ ed., v. 3. São Paulo: Saraiva, 2002.

GRAF, Amauri Milton. A resolução dos conflitos agrários sob a ótica da função social e dos movimentos sociais organizados. 2005, 97f. Monografia (Especialização em Direito Privado Contemporâneo) - Campus Universitário de Mafra, Universidade do Contestado, Mafra.

GUTERRES, José Augusto; CROCETTI, Priscila Soares. A propriedade da terra e a questão agrária brasileira. Revista da Faculdade de Direito UFPR, v. 43, p. 1-17, 2005.

IHERING, Rudolf Von. Teoria simplificada da posse. Trad. Ivo de Paula. São Paulo: Pilares, 2005.

JESUS, Carlos Frederico Ramos. Ocupações de terras rurais e o conceito de propriedade no direito brasileiro. Revista dos Tribunais, v. 53, p. 181, 2005.

LEMOS, Aline Maria da Rocha. Tutela antecipatória nas lides possessórias: necessidade de resguardo da função social. Revista do Curso de Direito da UNIFACS, n. 146, 2012.

LEONETTI, Carlos Araújo. Função social da propriedade: mito ou realidade? Novos Estudos Jurídicos, v. 5, n. 8, p. 17-26, 2009.

MARÉS, Carlos Frederico. A função social da terra. Porto Alegre: Sergio Antonio Fabris Editor, 2003.

MARQUES, Benedito Ferreira. CIDADANIA AGRÁRIA. Revista da Faculdade de Direito da UFG, v. 31, n. 1, p. 13-31, 2010.

MOREIRA, Sandra Mara Vale. A posse e a função social da propriedade agrária. Pensar, Fortaleza, v. 9, n. 9, p. 111-120, 2004.

NASCIMENTO, Tupinamba Miguel Castro. Posse e propriedade. Rio de Janeiro: AIDE, 1986. 
ORRUTEA, Rogério Moreira. Da propriedade e a sua função social no direito constitucional moderno. Londrina: UEL, 1998.

PEREIRA, Caio Mário da Silva. Instituições de direito civil: direitos reais. $20^{\text {a }}$ ed. v. IV, Rio de Janeiro: Forense, 2009.

PERES NETO, Heitor de Azevedo Picanço. A função social da propriedade rural na visão do Supremo Tribunal Federal, 2010, 106f. Dissertação (MESTRADO EM DIREITO AMBIENTAL E POLÍTICAS PÚBLICAS). Universidade Federal do Amapá, MACAPÁ, 2010.

PEROZZI, Silvio. Instituzioni di diritto romano. Roma: Athenaeum, 1906 apud BOLONHINI JUNIOR, Roberto. Uma nova visão fático-social da posse, 2013, 276f. Tese (Doutorado em Direito Civil Comparado). Pontifícia Universidade Católica de São Paulo, 2013.

SAMPAIO, Plínio de Arruda. A Reforma Agraria. Revista ABRA, ano 18. n. 2, 1988.

SANHUDO, João Paulo Veiga. Repersonalização da posse no direito brasileiro. Sapucaia do Sul: NotaDez, 2011.

SANTOS, Ozéias J. Da Posse: teoria, legislação, jurisprudência e prática. $1^{\text {a }}$ ed. v. I. São Paulo: Serrano, 1999.

SILVA, Jorge Gomes da. A reforma agrária brasileira na virada do milênio. Campinas: ABRA, 1996.

STRECK, Lenio. Hermenêutica jurídica e(m) crise: uma exploração hermenêutica da construção do direito. $11^{\mathrm{a}}$ ed. Livraria do Advogado: Porto Alegre, 2014.

TÁRREGA, Maria Cristina Vidotte Blanco et al. Observatório da atuação do Poder Judiciário nos conflitos agrários decorrentes de ocupações de terra por movimentos sociais nos estados do Pará, Mato Grosso, Goiás e Paraná (2003-2011): Relatório Final de Pesquisa / Maria Cristina Vidotte Blanco Tárrega, Cláudio Lopes Maia, Adegmar José Ferreira - Goiânia: Universidade Federal de Goiás / Faculdade de Direito, 2012.

TARTUCE, Flávio. Manual de direito civil. $4^{a}$ ed., rev. atual., v. único. São Paulo: Método, 2014.

TEPEDINO, Gustavo e SCHREIBER, Anderson. O papel do Poder Judiciário na efetivação da função social da propriedade. In: Questões agrárias: julgados comentados e pareceres. São Paulo: Método, 2002.

TORRES, Marcos Alcino de Azevedo. A propriedade e a posse: um confronto em torno da função social. Rio de Janeiro: Lumen Juris, 2007.

ZAVASCKI, Teori Albino. A tutela da posse na constituição e no novo código civil. Revista de Ciências Jurídicas, Direito e Democracia, v.5, n.1, p. 7-28, 2004.

A tutela da posse na constituição e no novo código civil. Revista Brasileira de Direito Constitucional, n. 5, p. 50-61, 2005. 